\title{
Comparative Study of E-Learning Experiences: A Case Study of Nigeria, South Africa and United States
}

\author{
Moses Timothy ${ }^{1 *}$, Oladunjoye John $\mathrm{A}^{2}$ and Agu Edward $\mathrm{O}^{3}$ \\ ${ }^{1,2,3}$ Computer Science Department, Federal University Wukari, \\ Taraba State, Nigeria \\ 1visittim@yahoo.com,2oladunjoye.abbey@yahoo.com,3wireh2004@yahoo.com
}

\begin{abstract}
We are in a society where availability of open courseware and countless internet-based online programmes are run by universities across the globe. The world is moving from the traditional face-to-face classroom teaching to a virtual classroom. There are concerns however; that this paradigm shift is limited by the understanding on what quality/standard is needed for a good e-learning resource. This concern has prompted the need to compare e-learning experiences in United States, South Africa and Nigeria so as to encourage developing countries to improve on this innovative approach to learning.
\end{abstract}

Keywords: Learning, e-learning, e-education, technology enabled infrastructure, virtual classroom

\section{Introduction}

The emergence of e-learning has revolutionized education sector with many universities and several higher education institutions expanding their programmes/activities by way of collaboration with other institution of learning. This innovative approach to learning has bridged distances and conserves classroom costs because of its availability any time and at students' convenience [10]. Materials and lecture notes are easily updated compared to old approach of traditional textbooks, communication channel between instructors and learners are open, the technology has enabled access to courses which otherwise would not have been possible [10]. Our old face-to-face system with one teacher - many learners in a classroom is now facing-off as many institutions are becoming more concerned with individual learning. Although this paradigm shift in learning has some contextual disparities when compared between developed and developing world [17], the technological revolution is playing an important role in the educational growth of any nation [5]. Developing countries like Nigeria are not left out of this global innovation, our universities these days have ventured in e-learning programmes thereby bringing us to a virtual classroom. Many institutions before now were using videotape-based training for their students. This is possible because the university community then represented a very small market and lack scalability that is important in today's application. [9] supported the idea of putting training on video; however, this idea lack customization based on needs of student, it is expensive to maintain and could not be upgraded easily. They are sometimes limited in terms of interaction between the trainer and the trainee. It became obvious that videotapes cannot be the best option in training students hence; the introduction of Computer Based Training (CBT) software like PowerPoint which marked an era of multimedia. CDROM were also introduced where an instructor can place his/her lecture notes on a CD for students to read. E-mail became a means through which instructors can communicate their students if there is any assignment or task to be performed [9]. Presently, prepared lectures notes are on web. Virtual Learning Environment has helped to place lecture notes online, along with supporting tools such as a linked glossary, contents page, and search 
tool. The advent of e-learning software has helped students get information/instructions from the web, interact with instructors and write exams [17].

E-learning can be described as the acquisition and use of knowledge distributed and facilitated primarily by electronic means [5]. The electronic means may include the use of web-based teaching materials and hypermedia, multimedia CD-ROMs, discussion boards, blogs, computer aided assessment, educational animations and through collaborative software [5]. Although there has been a great improvement in e-learning, some major drawbacks are eminent. The concept of e-learning still have challenges in the implementation of field work to students who study online. Projects/field work are most times on theoretical basis since e-learning give no room for students to regularly contact their instructors [17]. The objective of this paper is to study and give detailed comparison of the level of e-learning experiences in United States, South Africa and Nigeria so as to see what modalities will be needed to improve e-learning in most developing countries.

The next section will present a review of literature on the level of e-learning with some attributes serving as a means of comparison. The comparison will be illustrated on tabular form which will be followed by conclusion and recommendation.

\section{Literature Review}

With the availability of free open courseware and countless internet-based online programmes run by universities across the globe, people are now embracing e-learning. E-learning can be defined as an innovative approach for delivering of electronically mediated, well-designed learner-centered and interactive learning environments to students in any part of the world and at any time through internet and digital technologies. E-learning has attracted a number of research and development funding in institutions of learning. It has fuelled significant articles and reports on practice and guidance for the development of learning experiences. Generally, a number of factors have been identified for consideration in pursuit of the creation of good e-learning experiences. [11] identified technology, pedagogy and organizational context for a quality e-learning environment. [8] looked at the concept of cybernetics and activity theory as the basis for analysis and evaluation of e-learning environments. [6] in pursuit of evaluation criteria for e-learning considered appropriateness of staff and content, appropriateness for market and students, learning aspirations, cognitive ergonomics, faculty - student interaction, student - student interaction, reinforcement strategy and achievement of purpose. There are concerns however, that e-learning is limited by shortage of scientifically credible evaluation [13] and lack of understanding on what quality/standard is needed for a good e-learning resource [6]. These concerns have prompted the need to focus attention on e-learning experiences in United States, South Africa and Nigeria in an attempt to improve on this innovative approach to learning in developing countries. Five factors considered for comparison between these countries are prior ICT experience, virtual competence/capability, availability of e-learning infrastructure, cultural differences and motivation/assistance or support.

\subsection{Extent of Quality E-Learning Infrastructures}

To produce a successful e-learner will require the right and quality e-learning infrastructure [10]. These infrastructures include broadband connectivity, mobile-phone usage and PC availability/penetration. Across the board, the question is; are there internet services that reach more of society including rural residents and the poor? How readily available are internet facilities in our private homes and offices, government agencies, public settings including schools and libraries? Without the availability of internet connectivity, mobile and desktop systems, it will be difficult to learn online. The good news is that, our governments, both developed and developing countries are wise to 
continue prioritizing infrastructure rollout and upgrade. This development will help in the implementation of a good e-learning environment.

\subsection{Delivery Mode and Literacy Rates}

Observers have noticed that face-to-face, blended and e-learning delivery modalities are equal regardless of the means through which the lecture is delivered [20]. There is a sort of motivation that goes with having to study online and interact with instructors (people) you have not seen before [15]. It builds some confidence in the student to ask questions on areas he/she is not clear [15]. There are however, two major factors that influence students taking online courses. First is their prior experience on ICT and secondly, their virtual competence. With the absence of these two factors, students suffer from anxiety and are unable to meet up with their counterparts from other developed countries. The key to strong education system and high rate of literacy is enthusiasm for secondary and university schooling which must extend over classroom to become part of person's life. For e-learning to succeed broadly and not just within the four walls of traditional school setting, there must be a broad tradition of learning. Our government must also be ready to help by expanding training opportunities within their offices to make people know that, by continually improving skills, they continually improve their prospects.

\subsection{Availability of Rich Online Learning Materials}

E-learning readiness cannot be based only on connectivity and literacy rate alone. The most connected country may not produce top e-learners if there are no rich online learning materials [12]. A good e-learning platform should enable learners to access library materials, corporate information, government databases possibly in their native languages [12]. This contents help contributes to the strength and viability of structured e-learning programmes by schools and institutions. It is expected that in an e-learning environment, resources and text books are enriched. E - Books should be encouraged among online students rather than concentrating on prepared lecture notes on CDs or the e-learning portal [15]. How rich these books are can contribute to the success of e-learning. Creating a discussion forum on e-learning environment can help simulate thoughtful discussions among students and improve their level of understanding on a particular topic/issue [17]. It is important that any e-learning system give room for students to interact with each other and their instructors. Sometimes, what might be difficult to ask an instructor can be thrown to the discussion floor (forum) where students will contribute thereby given a deeper knowledge about a particular problem.

\subsection{Behaviour and Cultural Differences}

Though infrastructure, rich content and virtual competence can make e-learning possible, other factors like beliefs and behaviours of learners and institutions will flourish this innovative learning approach. Countries that tend to progress in e-learning programmes are countries where teaching profession is respected and rewarded, degree programmes are readily accepted, where government of the nation support and promote elearning, where there is general acceptance of this idea and a promise for e-learning ventures [16]. Since e-learning has become a global innovation, it has seen students from different cultural background and countries coming together under same tutelage. Their cultural differences have posed a major challenge and most special case is students from developing countries. Being aware of cultural difference and also been able to deal with it will be a critical success in the implementation of online learning programs. For a better e-learning environment therefore, government and institutions in a country must develop plans and policies to welcome e-learning programmes into public institutions, support the validity of online degrees and certificates and make effort to increase public acceptance 
and trust in online learning [16]. Assistance/support from individuals and companies will go a long way to help institutions that would want to implement online studies. It is important that government, individuals and non-governmental organizations (NGOs) look towards helping and encouraging these institutions put up e-learning environment. A well designed e-learning support system will create a constructive learning environment where everybody ends up learning from each other.

\section{Case Study}

\subsection{Case Study 1: Nigeria}

With all the efforts by Nigerian government to lay foundation for e-learning through investment in ICT infrastructure, Management Information System and Library Information Services for the last three decades, Nigeria still ranked $62^{\text {nd }}$ nation among other nations of the world in the use of ICT [2]. Most disappointing is that, even as the most populous country in African continent, Nigeria is ranked below South Africa and Egypt which ranked $39^{\text {th }}$ and $57^{\text {th }}$ respectively [2]. With the huge number of Nigeria's human capital and national endowment, the country cannot be counted among progressive nations fully implementing e-learning in educational management [3]. It has become difficult to replace traditional pedagogical practices that still underpin its educational system [3]. Major issue facing the adoption and application of e-learning system is the attitude of school management and authorities to provide and install ICT infrastructure. Apart from ICT infrastructures, stable electricity supply is another formidable challenge, not enough skilled teachers to utilize e-learning technology in curriculum implementation, hence the traditional chalk and duster approach [3]. Where ICT infrastructures are available, network and low/limited bandwidth pose a greater challenge in Nigeria. The National Open University of Nigeria (NOUN) established in July, 1983, by an Act of the National Assembly as the first distance learning tertiary institution in Nigeria still have prepared lecture notes placed on a CD-ROM which is played by the students whenever they want to read [1]. Sometimes, these CD's are given to students with no idea as to whether they have a computer system or not. In institutions where computers are available, hardly will you see a student per system, it is either three students struggling with a system and sometimes, the system might not come-up till the end of the class. The intranet facilities found in most NOUN satellite campuses are not well maintained because of the problem of electricity. NOUN has commenced plan on the introduction of more electronic media like CD-ROM, e-mail, internet and interactive e-learning systems for its courses delivery [1]. National Communication Commission (NCC) has started the distribution of CmPCs (Class Mate PCs) in most secondary school with software that facilitate e-learning. We hope that this qualitative innovation will bring us to a wellstructured e-learning environment.

A research to investigate e-learning in Nigerian universities considering availability of e-learning facilities and e-learning materials for students to undergo e-learning programmes was conducted by [2]. Sample size of 228 students from six geopolitical zones of Nigeria constituted their population and results obtained are shown in table 1,2 and 3 respectively. 
Table 1. Availability of Facilities for E-Learning in Nigerian Universities

\begin{tabular}{|c|c|c|c|c|c|c|}
\hline No & Description & Yes & $\%$ & No & $\%$ & Total \\
\hline 1. & Your university has an e-library domain & 102 & 45 & 126 & 55 & 228 \\
\hline 2. & $\begin{array}{l}\text { You can check online learning resources } \\
\text { on at least one of the following desktop } \\
\text { computer, laptop computer, cell or mobile } \\
\text { phone with MP } 3 \text { capability. }\end{array}$ & 122 & 54 & 106 & 46 & 228 \\
\hline 3. & $\begin{array}{l}\text { The online learning resources is } \\
\text { compatible with atleast one of the } \\
\text { following operating system, Win 98, Win } \\
\text { 200, Win XP, Win Vista, Mac OS, } \\
\text { Unix/Linux }\end{array}$ & 130 & 57 & 98 & 43 & 228 \\
\hline 4. & $\begin{array}{l}\text { The online learning resources is } \\
\text { compatible with at least one of the } \\
\text { following browser; Netscape, Microsoft } \\
\text { Internet Explorer, Mozilla Firefox, Google } \\
\text { chrome. }\end{array}$ & 130 & 57 & 98 & 43 & 228 \\
\hline 5. & My bandwidth is limited & 126 & $5 \mathrm{i}$ & 102 & 49 & 228 \\
\hline 6. & My electricity supply is limited & 127 & 56 & 101 & 44 & 228 \\
\hline
\end{tabular}

Table 2. Availability of E-learning Materials in Nigerian Universities

\begin{tabular}{|l|l|c|c|c|c|c|}
\hline No & \multicolumn{1}{|c|}{ Description } & Yes & \% & No & \% & Total \\
\hline 1. & $\begin{array}{l}\text { A clear statement of all online based course } \\
\text { requirements was provided at the } \\
\text { beginning of the course. }\end{array}$ & 111 & 49 & 117 & 51 & 228 \\
\hline 2. & $\begin{array}{l}\text { Your university has educational software } \\
\text { for teaching }\end{array}$ & 102 & 45 & 116 & 55 & 228 \\
\hline 3. & $\begin{array}{l}\text { All online learning materials and resources } \\
\text { were understandable }\end{array}$ & 82 & 36 & 120 & 64 & 228 \\
\hline 4. & $\begin{array}{l}\text { The online materials were interesting and } \\
\text { engaging }\end{array}$ & 89 & 39 & 139 & 61 & 228 \\
\hline 5. & The course activities helped me learn & 97 & 31 & 131 & 69 & 228 \\
\hline
\end{tabular}

Table 3. Use of e-learning Platform by Students in Nigerian Universities

\begin{tabular}{|l|l|c|c|c|c|c|}
\hline No & \multicolumn{1}{|c|}{ Description } & Yes & \% & No & \% & Total \\
\hline 1. & $\begin{array}{l}\text { You engage in online seminars and } \\
\text { discussion with your lecturers weekly. }\end{array}$ & 100 & 44 & 128 & 56 & 228 \\
\hline 2. & $\begin{array}{l}\text { All my online instructors or tutors could be } \\
\text { contacted easily }\end{array}$ & 102 & 45 & 116 & 55 & 228 \\
\hline 3. & You receive lecturers online weekly & 98 & 43 & 120 & 57 & 228 \\
\hline 4. & You receive and submit assignment online & 77 & 34 & 151 & 66 & 228 \\
\hline 5. & You sit for examination online & 91 & 40 & 137 & 60 & 228 \\
\hline
\end{tabular}

It was concluded by [2] that, although there are developments in Nigeria education section as regards application of ICT and adoption of e-learning, there are still many challenges. ICT infrastructures like computer hardware and software, network/bandwidth necessary for deploying an effective ICT platform was lacking in Nigeria. Also, 
inadequate internet access in some tertiary institutions, acute shortages of trained personnel who can handle e-learning software has posed a major challenge in the administration of e-learning in Nigeria [2].

\subsection{Case Study 2: South Africa}

Though e-learning has come of age in South African higher education, skepticism, caution and inadequate reward system for innovative teaching methods has resulted in its slow uptake by academics. As far back August, 2003, a draft white paper was drawn which contains ten year plan for promoting e-learning in South Africa [19]. The plan has it that e-learning be phased in three stages; phase one is to enhance a system-wide institutional readiness to use ICT for learning, teaching and administration. Phase two is the actual system -wide integration of ICT into teaching and learning, while phase three sees to it that ICT is integrated at all levels of the education system - management, teaching, learning and administration [19]. By 2004 however, comments and points of criticism were made by [7] on the draft white paper. Access issues such as bandwidth problems in rural areas are not mentioned, there is no proper coordination with the institution supplying electricity, telecommunications and e-service. The paper focuses on schools with no special consideration for other learning environment, translation applications for content in the eleven official languages was not stressed [7]. We can therefore, deduce that there is disparity between e-learning ideals formulated by South African education policy makers and what is obtainable as e-learning practices in South Africa. Most important is the case in rural or disadvantaged areas of the country. To bridge this gap, University of South Africa (UNISA) prides itself by providing access and promoting African thought, interest and epistemologies to students irrespective of where they are. To fulfill its mandate, the university established seven regional centres as a way to decentralize its services [21]. Table 4, below shows UNISA regional centres.

Table 4. UNISA Regional Centres

\begin{tabular}{|l|l|l|}
\hline \multicolumn{1}{|c|}{ Region } & \multicolumn{1}{|c|}{ City/Hub } & \multicolumn{1}{|c|}{$\begin{array}{c}\text { Geographical spread (provinces and } \\
\text { neighbouring countries) }\end{array}$} \\
\hline Gauteng & Pretoria & Gauteng Province \\
\hline kwaZulu Natal & Durban & KwaZulu-Natal Province \\
\hline Western Cape & Cape Town & $\begin{array}{l}\text { Western Cape Province and part of the } \\
\text { Northern Cape and Nambia }\end{array}$ \\
\hline Limpopo & Polokwane & Limpopo Province and Zimbabwe \\
\hline Eastern Cape & East London & Eastern Cape Province \\
\hline Mpumalanga & Nelspruit & $\begin{array}{l}\text { Mpumalanga Province, Swaziland and } \\
\text { Mozambique }\end{array}$ \\
\hline Midlands & Rustenburg & $\begin{array}{l}\text { North West, Free State and Northern Cape } \\
\text { Provinces }\end{array}$ \\
\hline
\end{tabular}

Source: [21].

Knowing that e-learning relies heavily on technology-enabled learning equipment like network, bandwidth, availability of computers and other related infrastructures and resources, Table 5, below shows the number of support staff and available computers visà-vis the number of registered students in one of UNISA's regional centres (the Eastern Cape region). 
Table 5. Human and Computer Resources

\begin{tabular}{|l|l|l|l|}
\hline \multicolumn{1}{|c|}{ Centre } & $\begin{array}{c}\text { No of permanent } \\
\text { staff }\end{array}$ & No of students & No of computers \\
\hline Eat London & 15 & 7715 & 15 \\
\hline Mthatha & 13 & 7621 & 34 \\
\hline Port Elizabeth & 5 & 6024 & 14 \\
\hline Grand Total & 32 & 21360 & 63 \\
\hline
\end{tabular}

Source: [21].

From Table 5, we can deduce that there is a wide gap between the number of human and computer resources to the number of students in the region. Speed of access to internet and bandwidth size is another major challenge. According to [21], 50\% of respondents from Port Elizabeth and Mthatha reported low network and bandwidth size with $40 \%$ respondents from East London sharing same sentiment [21]. Some respondents surprisingly reported that not all computers are connected to the internet. Network connectivity is unanimously agreed to be unreliable in this region. Also, indefinite electricity blackout is a major issue [21].

Staff aptitude and attitude is another notable challenge in this region [21]. Table 6, 7, and 8 , shows how staff responds to student's queries, ability to operate UNISA systems like myUnisa and staff response as to whether the region is ready to implement e-learning respectively [21].

Table 6. Staff has been Trained to Facilitate Student Queries

\begin{tabular}{|l|l|l|l|l|l|}
\hline $\begin{array}{c}\text { Staff } \\
\text { Grade } \\
\text { Level }\end{array}$ & $\begin{array}{c}\text { Strongly } \\
\text { disagreed }\end{array}$ & Disagree & Not Sure & Agree & $\begin{array}{c}\text { Strongly } \\
\text { Agree }\end{array}$ \\
\hline P6 & $0 \%$ & $100 \%$ & $0 \%$ & $0 \%$ & $0 \%$ \\
\hline P7 & $30.8 \%$ & $23.1 \%$ & $38.5 \%$ & $0 \%$ & $7.7 \%$ \\
\hline P8 & $0 \%$ & $0 \%$ & $100 \%$ & $0 \%$ & $0 \%$ \\
\hline P9 & $100 \%$ & $0 \%$ & $0 \%$ & $0 \%$ & $0 \%$ \\
\hline P10 & $0 \%$ & $0 \%$ & $100 \%$ & $0 \%$ & $0 \%$ \\
\hline Others & $24 \%$ & $32 \%$ & $36 \%$ & $4 \%$ & $4 \%$ \\
\hline
\end{tabular}

Source: [21].

Table 7. Staff knows how to Operate Unisa Systems (e.g. myUnisa, Online Library, Social Networks

\begin{tabular}{|l|l|l|l|l|l|}
\hline $\begin{array}{c}\text { Staff Grade } \\
\text { Level }\end{array}$ & $\begin{array}{c}\text { Strongly } \\
\text { disagreed }\end{array}$ & Disagree & Not Sure & Agree & $\begin{array}{c}\text { Strongly } \\
\text { Agree }\end{array}$ \\
\hline P6 & $0 \%$ & $0 \%$ & $0 \%$ & $100 \%$ & $0 \%$ \\
\hline P7 & $7.7 \%$ & $15.4 \%$ & $38.5 \%$ & $23.1 \%$ & $15.4 \%$ \\
\hline P8 & $0 \%$ & $0 \%$ & $0 \%$ & $100 \%$ & $0 \%$ \\
\hline P9 & $0 \%$ & $0 \%$ & $0 \%$ & $100 \%$ & $0 \%$ \\
\hline P10 & $0 \%$ & $0 \%$ & $100 \%$ & $0 \%$ & $0 \%$ \\
\hline Others & $12 \%$ & $16 \%$ & $24 \%$ & $36 \%$ & $12 \%$ \\
\hline
\end{tabular}

Source: [21]. 
Table 8. Staff Reckons that the Region is Ready to Implement e-learning

\begin{tabular}{|l|l|l|l|l|l|}
\hline $\begin{array}{c}\text { Staff } \\
\text { Grade } \\
\text { Level }\end{array}$ & $\begin{array}{c}\text { Strongly } \\
\text { disagreed }\end{array}$ & Disagree & Not Sure & Agree & $\begin{array}{c}\text { Strongly } \\
\text { Agree }\end{array}$ \\
\hline P6 & $0 \%$ & $0 \%$ & $100 \%$ & $0 \%$ & $0 \%$ \\
\hline P7 & $30.8 \%$ & $23.1 \%$ & $38.5 \%$ & $7.7 \%$ & $0 \%$ \\
\hline P8 & $0 \%$ & $0 \%$ & $0 \%$ & $100 \%$ & $0 \%$ \\
\hline P9 & $0 \%$ & $100 \%$ & $0 \%$ & $0 \%$ & $0 \%$ \\
\hline P10 & $0 \%$ & $0 \%$ & $0 \%$ & $100 \%$ & $0 \%$ \\
\hline Others & $20 \%$ & $28 \%$ & $32 \%$ & $16 \%$ & $4 \%$ \\
\hline
\end{tabular}

Source: [21].

Though Table 7, shows that most staff knows how to operate Unisa Systems, there is no clarity on specific skills needed for e-learning implementation hence, no assurance of the appropriateness of skills acquired by these staff. Deduction that can be made from draft white paper on e-education [19], comments and points of criticism as reported by [7] and reflections on the readiness of one of UNISA regional centres staff [21] is that, though University of South Africa has considerable better e-learning experience, its regional centres or rural areas lack clarity on the nature, goals and implications of elearning.

\subsection{Case Study 3: United States}

Undisputable, United States stands as the current leader in online education in the world today [14]. United States has more than hundreds of online colleges and thousands of online courses available to students [14]. It was reported that 6 million students in United States are taking at least one online course and up to one third of all students enrolled in higher education take their courses online [18].

A report on tracking online education in the United States presented by [4] shows a considerable diversity among course delivery methods used by individual instructors in United States. Table 9, below shows these classifications.

Table 9. Course Delivery Methods Used by Individual Instructors in United States

\begin{tabular}{|l|l|l|}
\hline $\begin{array}{c}\text { Proportion of } \\
\text { content } \\
\text { delivered } \\
\text { online }\end{array}$ & Type of Course & \multicolumn{1}{|c|}{ Typical Description } \\
\hline $0 \%$ & Traditional & $\begin{array}{l}\text { Course where no online technology is used - } \\
\text { content is delivered in writing or orally. }\end{array}$ \\
\hline $1-29 \%$ & Web facilitated & $\begin{array}{l}\text { Course that uses web-based technology to } \\
\text { facilitate what is essentially a face-to-face } \\
\text { course. May use a course management } \\
\text { system (CMS) or web pages to post the } \\
\text { syllabus and assignments. }\end{array}$ \\
\hline $30-79 \%$ & Blended/Hybrid & $\begin{array}{l}\text { Course that blends online and face-to-face } \\
\text { delivery. Substantial proportion of the } \\
\text { content is delivered online, typically uses } \\
\text { online discussions, and typically has a } \\
\text { reduced number of face-to-face meetings. }\end{array}$ \\
\hline $80 \%+$ & Online & A course where most or all of the content is \\
\hline
\end{tabular}




\begin{tabular}{|l|l|l|}
\hline & & $\begin{array}{l}\text { delivered online. Typically have no face-to- } \\
\text { face meetings. }\end{array}$ \\
\hline
\end{tabular}

Source: [4].

Table 9, above shows a massive move from traditional way of learning to online learning system. This is a sharp contrast to what is obtainable in Nigeria and South Africa where most of the courses are presented in writing or blended form.

\subsection{Comparison between Nigeria, South Africa and United States E-Learning Experiences}

Table 10, below shows comparison on the extent of quality e-learning infrastructures, delivery mode and literacy rates, availability of rich online learning materials and behavior and cultural differences in Nigeria, South Africa and United States.

Table 10. Comparison between Nigeria, South Africa and United States ELearning Experiences

\begin{tabular}{|c|c|c|c|c|}
\hline Country $\rightarrow$ & $\begin{array}{c}\text { Extent of quality e- } \\
\text { learning } \\
\text { infrastructures }\end{array}$ & $\begin{array}{l}\text { Delivery mode and } \\
\text { literacy rates }\end{array}$ & $\begin{array}{c}\text { Availability of rich } \\
\text { online learning } \\
\text { materials }\end{array}$ & $\begin{array}{l}\text { Behavioural and } \\
\text { cultural differences }\end{array}$ \\
\hline Nigeria & $\begin{array}{l}\text { Poor technological } \\
\text { infrastructures. } \\
\text { Little or no } \\
\text { assistance/support } \\
\text { to provide } \\
\text { technology-enabled } \\
\text { learning equipment } \\
\text { by government. }\end{array}$ & $\begin{array}{l}\text { Courses still on CDs } \\
\text { and printed materials. } \\
\text { Rigorous study pattern } \\
\text { with no flexibility of } \\
\text { schedules for students. } \\
\text { Computer literacy } \\
\text { though moderate, } \\
\text { staff/students training } \\
\text { on e-learning system } \\
\text { still at infancy level. }\end{array}$ & $\begin{array}{lr}\text { Poor web portal } \\
\text { structure with very } \\
\text { poor contents. Online } \\
\text { contents only in } \\
\text { English language } \\
\text { hence, non-English } \\
\text { speaking e-learners } \\
\text { cannot enroll in online } \\
\text { programme. Suggested } \\
\text { books from online } \\
\text { content not always } \\
\text { available. }\end{array}$ & $\begin{array}{l}\text { Staff/students } \\
\text { motivation by } \\
\text { government is very low. } \\
\text { Only few coordinators } \\
\text { supervise instructors at } \\
\text { various study centers. }\end{array}$ \\
\hline South Africa & $\begin{array}{l}\text { Moderate } \\
\text { technological } \\
\text { infrastructures. } \\
\text { Considerable } \\
\text { assistance/support } \\
\text { by South African } \\
\text { government to } \\
\text { provide technology- } \\
\text { enabled learning } \\
\text { equipment. }\end{array}$ & 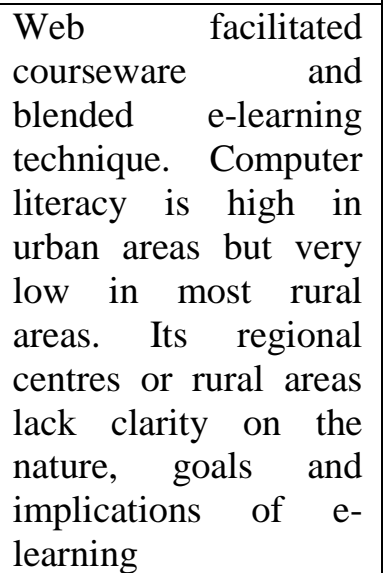 & 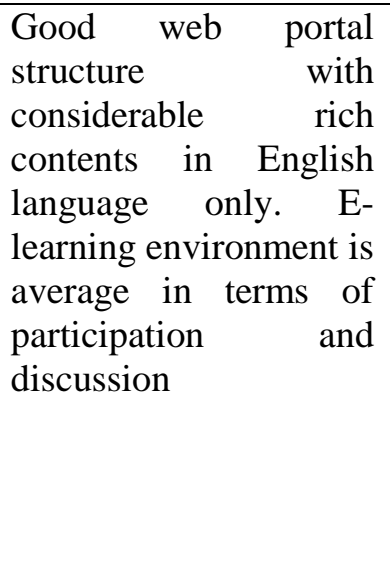 & $\begin{array}{l}\text { Staff/students } \\
\text { motivation is very low } \\
\text { especially in the rural } \\
\text { areas. Government } \\
\text { policy on e-Education } \\
\text { has no special } \\
\text { consideration for } \\
\text { learners in most rural } \\
\text { communities. }\end{array}$ \\
\hline United States & $\begin{array}{l}\text { Good technological } \\
\text { infrastructures with } \\
\text { government craving } \\
\text { to do more so as to } \\
\text { meet needs of e- } \\
\text { learners. Network } \\
\text { access and } \\
\text { bandwidth is very }\end{array}$ & $\begin{array}{l}\text { Most or all of the } \\
\text { courseware content is } \\
\text { delivered online. } \\
\text { Computer literacy is } \\
\text { extremely high with } \\
\text { students knowing how } \\
\text { to navigate and use e- } \\
\text { learning systems. }\end{array}$ & $\begin{array}{l}\text { Very good portal; uses } \\
\text { Virtual Learning } \\
\text { Environment. Contents } \\
\text { are very rich with real } \\
\text { world illustrations that } \\
\text { can build learner's } \\
\text { technical skills. Have } \\
\text { good online classroom }\end{array}$ & $\begin{array}{l}\text { Staff/students } \\
\text { motivation is high. } \\
\text { Assistance/support is } \\
\text { always the concern of } \\
\text { government. Rigorous } \\
\text { training of staff both at } \\
\text { the induction phase and } \\
\text { at interval as the }\end{array}$ \\
\hline
\end{tabular}




\begin{tabular}{|l|l|l|l|l|}
\hline & $\begin{array}{l}\text { high which allow } \\
\text { students to partake } \\
\text { in full online } \\
\text { studies. }\end{array}$ & $\begin{array}{l}\text { and video repository. } \\
\text { E-learning system } \\
\text { provides synchronous } \\
\text { communication } \\
\text { between teacher and } \\
\text { student. }\end{array}$ & \\
\hline
\end{tabular}

\section{Conclusion and Recommendation}

\subsection{Conclusion}

This paper has looked at e-learning experiences from three different countries with emphasis on the quality of e-learning infrastructures, delivery mode and literacy rates, availability of rich online materials, behaviour and cultural differences. Experiences gathered from these three countries shown a common misconception that e-learning is mainly about technology. However, learning goes beyond just technology, it also involves learners' attitudes, beliefs, capabilities, knowledge structure and behaviour towards learning. How a learner engage with e-learning materials and activities, couple with literacy rate will enhance effective e-learning. Failure to realize the difference between technology and learner's attitude is probability the most common explanation for many student drop-outs from online courses.

\subsection{Recommendation}

Advancement in technology is changing the face of education, leaving us with no option than to change our attitudes towards e-learning. From experiences gathered in this paper, we present the following recommendations for effective e-learning teaching.

1. Government, non-governmental organizations and individual alike should assist in the introduction and development of e-learning environment in most of our institutions.

2. Lecture delivery note in online education is a significant issue, hence IT professionals should come together to develop a constructive e-learning environment having features discussed in section two of this paper.

3. This environment should also provide excellent user - interface so as to ease learning between students and instructor.

4. It is also very important to review curriculums we have in developing countries so as to meet current trend as obtained in developed countries.

5. Instructors should be well trained and motivated to facilitate effective learning.

6. Students should go into pre-training programmes before commencing any online course.

\section{References}

[1] T. O. Ajadi, I. O. Salawu and F. A. Adeoye, "E-Learning and distance education in Nigeria", The Turkish Online Journal of Educational Technology, vol. 7, no. 4, (2008).

[2] J. N. Anene, H. Imam and T. Odumuh, "Problems and prospect of e-learning in Nigerian universities", International Journal of Technology and Inclusive Education (IJTIE), vol. 3, no. 2, (2014), pp. 320-327.

[3] S. O. Amedu, "Assessment of the use of e-learning facilities by Home Economics Teachers in Delta State, Nigeria", Journal of education and practice, vol 5, no. 16, (2014), pp. 207-212.

[4] I. E. Allen and J. Seaman, "Grade change: tracking online education in the United States", Babson Survey Research Group, United States, (2014).

[5] S. K. Behera, "E- and M- Learning: A comparative study", International Journal on New Trends in Education and their Implications, vol. 3, no. 08, (2013), pp. 65-78.

[6] E. Blass and A. Davis, "Building on solid foundations: establishing criteria for e-learning development", Journal of further and higher education, vol. 27, no. 3, (2003), pp. 227-245. 
[7] Bridge.org, "Comment submitted by bridge.org on the draft e-Education white paper". Retrieved 10 August, 2015 from http://www.bridge.org/e-policy/sa/submissions/e-education.htm, (2004).

[8] S. Britain and O. Liber, "A framework for pedagogical evaluation of virtual learning environments", Institute for Education Cybernetics, report paper 2 London, (2000).

[9] M. Cooke, "Clomedia: The evolution of e-learning", Retrieved August 21, 2015 from http://www.clomedia.com/content/templates/clo_webonly.asp?articleid=571\&zoneid=78, (2004).

[10] EIU, "Digital economic ranking 2010: Beyond e-readiness", A white paper from the Economist Intelligent Unit, London, (2010).

[11] D. R. Garrison and T. Anderson, "E-learning in the $21^{\text {st }}$ century: a framework for research and practice", Abingdon Routledge, (2003).

[12] S. Gulati, "Technology-enhanced learning in developing nations: A review", International Review of Research in Open and Distributed Learning, UK, (2008).

[13] J. Hughes and G. Attwell, "A framework for the evaluation of e-learning", Paper presented to a seminar series on Exploring Models and Partnerships for eLearning in SME's, held in Stirling, Scotland and Brussels, Belgium, Retrieved 14 September, 2015, from http://www.theknownet.com/ict_smes_seminars/papers/, (2003).

[14] ICEF Monitor, "8 countries leading the way in online education", Retrieved 20 September, 2015 from http://www.monitor.icef.com, (2012).

[15] Q. Liu and Z. Sun, "Research on e-learning resources organizing strategy", Proceedings of the 2008 International Symposium on Computational Intelligence and Design, IEEE Computer Society, Washington DC, USA, vol. 1, (2008).

[16] M. Nakayama, K. Mutsuura and H. Yamamoto, "Impact of learner's characteristics and learning behavior on learning performance during a fully online course", The Electronic Journal of e-learning, vol. 12, no. 4, (2014), pp. 394-408.

[17] A. Nawaz, "Using e-learning as a tool for "education for all" in developing states", International Journal of Science and Technology Education Research, vol. 4, no. 3, (2013), pp. 38-46.

[18] S. Consortium, "Online learning consortium", Retrieved 20 September, 2015 from http://www.olc.onlinelearningconsortium.org/publications/survey/going-distance_2011, (2011).

[19] South African white paper on e-Education, "Transforming learning and teaching through ICT", Department of Education, South Africa, (2003).

[20] M. Tang and R. Byrne, "Regular versus online versus blended: A qualitative description of the advantages of the electronic modes and a quantitative evaluation", International Journal on E-Learning, vol, 6, no. 2, (2007), pp. 257-266.

[21] H. Thunyelwa and D. Luyanda, "Reflection on the readiness of the University of South Africa Eastern Cape Region for the development of e-learning", Mediterranean Journal of Social Sciences, MCSER Publishing, Rome- Italy, (2014). 
International Journal of Grid and Distributed Computing Vol. 9, No. 10 (2016) 